\title{
Classic and novel brominated flame retardants (BFRs) in common sole (Solea solea L.) from main nursery zones along the French coasts
}

\author{
C. Munschy ${ }^{a,{ }^{*}}$, K. Héas-Moisan ${ }^{a}$, C. Tixier $^{a}$, L. Boulesteix ${ }^{a}$, J. Morin $^{b}$

\begin{abstract}
a IFREMER (Institut Français de Recherche pour l'Exploitation de la Mer), Laboratory of Biogeochemistry of Organic Contaminants, Rue de l'lle d'Yeu, BP 21105, 44311 Nantes Cedex 3, France

b IFREMER (Institut Français de Recherche pour l'Exploitation de la Mer), Laboratory of Fishery Resources, Avenue du Général de Gaulle, 14520 Port-en-Bessin, France
\end{abstract} \\ *: Corresponding author : Catherine Munschy, tel. : +33 (0)2 40374224 ; fax : +33 (0)2 40374075 \\ email address : cmunschy@ifremer.fr
}

\begin{abstract}
:
Brominated flame retardants (BFRs) were investigated in juvenile common sole from nursery zones situated along the French coast in 2007, 2008 and 2009. Extensive identification was performed with regard to PBDEs, novel BFRs 1,2-bis(2,4,6-tribromophenoxy)ethane (BTBPE) and decabromodiphenylethane (DBDPE), and other non-PBDE BFRs, namely, hexabromobenzene (HBB) and 2,2',4,4',5,5'-hexabromobiphenyl (BB-153). Polybrominated diphenyl ether (PBDE) concentrations ( $\Sigma 14$ congeners) ranged from $0.01 \mathrm{ng} / \mathrm{g}$ to $0.16 \mathrm{ng} / \mathrm{g}$ wet weight (ww) in muscle, and $0.07 \mathrm{ng} / \mathrm{g}$ to 2.8 $\mathrm{ng} / \mathrm{g}$ ww in liver. Concentrations were in the lower range of those reported in the literature in other European locations. Lower PBDE concentrations, condition indices and lipid contents were observed in the Seine estuary in 2009, possibly in relation to a lower water flow. The PBDE patterns and ratios we observed suggested that juvenile sole have a relative high metabolic degradation capacity. NonPBDE BFRs were detected at lower levels than PBDEs, i.e., within the < method detection limit $0.005 \mathrm{ng} / \mathrm{g}$ ww range in muscle, and < method detection limit $-0.2 \mathrm{ng} / \mathrm{g}$ ww range in liver. The data obtained is of particular interest for the future monitoring of these compounds in the environment.
\end{abstract}

\section{Highlights}

PBDEs and novel BFRs were investigated in common sole from French nursery zones. Concentrations were in the lower range of those reported in other European locations. Novel BFR concentrations did not show any increase compared to previous years. PBDE congener patterns and ratios suggested a high metabolic degradation capacity.

Keywords : Polybrominated diphenyl ethers (PBDEs) ; Novel brominated flame retardants (NBFRs) ; French coastal nurseries ; Benthic fish; Sole ; Patterns 


\section{Introduction}

Coastal and estuarine areas are major nursery zones for a variety of species, in particular flatfish (Riou et al., 2001). These zones receive contaminant inputs from various human activities, which may lead to a deterioration in flatfish habitat quality, hence affecting species number and density, and the recruitment of adult populations (Courrat et al., 2009; Rochette et al., 2010). Common sole was chosen as the target species for this study due to its benthic habitat and potential exposure to sedimentassociated persistent organic contaminants, such as polybrominated diphenyl ethers (PBDEs), plus its high commercial value for European coastal regions (Riou et al., 2001; Nicolas et al., 2007).

Brominated flame retardants (BFRs), including PBDEs, have been the focus of numerous studies for the past 10 years, as their presence has been demonstrated worldwide and in all environmental compartments (de Wit, 2002; Law et al., 2003; Hites, 2004; Law et al., 2006b; Tanabe, 2008; Shaw and Kannan, 2009). Their physicochemical properties and fate in the environment (persistence, bioaccumulation, long-range transport and toxicity) qualify them as persistent organic pollutants (POPs); as a result, commercial Penta-bromodiphenyl ether and Octa-bromodiphenyl ether have been added to the list of POPs established by the United Nations Stockholm Convention in May 2009 (Stockholm Convention, 2009). PBDEs also feature on the list of priority substances drawn up by the European Water Framework Directive (Decision 2455/2001/EC). The commercial mixtures Penta-bromodiphenyl ether and Octabromodiphenyl ether have been banned from the European market since 2003 (Directive 2003/11/EC). DecaBDE remains on the list of authorized chemicals, although it has been banned in certain EU consumer products since July 2008 (BSEF, 2011). Over 67,000 metric tons of PBDEs were produced worldwide in 2001, mostly (over 80 \%) comprising Deca-bromodiphenyl ether (DecaBDE) (Law et al., 2006b). BDE-209 accumulation in sediment has recently become a matter of concern, as this compartment represents large environmental reservoirs and could therefore be a potential threat to biota in the long-term (Ross et al., 2009). PBDEs are cause for concern due to their potential adverse effects on wildlife and humans, including endocrine disruption, immunotoxicity and neurotoxicity (Shaw and Kannan, 2009). As a number of PBDEs are currently banned, alternative flame-retardants have now been introduced onto the world market. The levels of these replacement BFRs (or "novel" BFRs) are thus likely to increase in the environment. These compounds have recently been identified in the Arctic, demonstrating their long-range transport capability, and have been shown to accumulate in higher trophic level organisms (de Wit et al., 2010; Möller et al., 2011). To date, little is known about their potential toxicity to wildlife and humans (Stapleton et al., 2008). Among non-PBDE BFRs, decabromodiphenyl ethane (DBDPE), 1,2-bis(2,4,6-tribromophenoxy)ethane (BTBPE), hexabromobenzene (HBB) and $2,2^{\prime}, 4,4^{\prime}, 5,5^{\prime}$-hexabromobiphenyl (BB-153) were specifically targeted in this study. Current data on the occurrence of these non-PBDE BFRs in French coastal areas is very scarce (Munschy et al., 2007).

DBDPE was introduced in the early 1990s as an alternative to BDE-209 in plastic and textile applications (Ricklund et al., 2010). DBDPE is qualified as a low production volume chemical ( $<1000$ tons/year) by the EU (European chemical Substance Information System - ESIS, http://ecb.jrc.ec.europa.eu/esis/). This highly hydrophobic compound ( $\log \mathrm{K}_{\mathrm{ow}}$ of 11.1, Covaci et al., 2011) has been identified in sewage sludge, sediment, indoor dust and biota, and it has been qualified as a widespread contaminant (Kierkegaard et al., 2004; Ricklund et al., 2008; Shi et al., 2009; Ricklund et al., 2010; 
Ali et al., 2011; Covaci et al., 2011). Although France was not covered by the Ricklund et al. (2008) study, DBDPE levels in sludge from various countries were found to be higher in Europe than in North America.

BTBPE was first produced in the 1970s and is used as a replacement for octaBDEs (Hoh et al., 2005). Worldwide production or estimated use was 16,710 metric tons in 2001 (Verreault et al., 2007). Like DBDPE, BTBPE is identified as a low production volume chemical (< 1000 tons/year) by the EU (ESIS, http://ecb.jrc.ec.europa.eu/esis/). BTBPE has been identified in various abiotic media (indoor dust, atmosphere, sediment, water) and biotic media (zooplankton, mussel, fish, aquatic bird eggs) (Hoh et al., 2005; Law et al., 2006a; Gauthier et al., 2009; Shi et al., 2009; Ali et al., 2011; Covaci et al., 2011). This compound (log $\mathrm{K}_{\mathrm{ow}}$ of 7.88, Covaci et al., 2011) has been shown to bioaccumulate in various aquatic species and has the ability to biomagnify in aquatic food webs (Law et al., 2006a; Tomy et al., 2007; Wu et al., 2011).

HBB used to be commonly used for the manufacture of paper, woods, textiles, plastics and electronic goods in Japan, and is currently employed in small volumes (Yamaguchi et al., 1988; Watanabe and Sakai, 2003). Thermal degradation of the DecaBDE technical mixture and polymeric PBDEs pyrolysis could also be sources of the HBB found in the environment (Thoma and Hutzinger, 1987; Gouteux et al., 2008). HBB is not qualified by the EU as either a high or low production volume substance (ESIS, http://ecb.jrc.ec.europa.eu/esis/). HBB has been identified in river and estuary sediment and in human adipose tissue in Japan (Watanabe et al., 1986; Yamaguchi et al., 1988), in the atmosphere and biota of the Great Lakes (Gouteux et al., 2008; Gauthier et al., 2009), China (Qiu et al., 2010; Wu et al., 2010) and the Arctic (Verreault et al., 2007; Möller et al., 2011).

BB-153 is the main constituent of technical hexabromobiphenyl: one of the three polybrominated biphenyl (PBB) technical mixtures, used as flame retardant in electronic equipment. PBBs are no longer commercially-produced on a worldwide basis (Sjödin et al., 2004), but one company in France continued to manufacture technical decabromobiphenyl until the year 2000 (Hardy, 2002). In the United States, a decreasing trend in BB-153 in human serum was revealed between 1985 and 2002, following the ban on its use in the mid-Seventies (Sjödin et al., 2004). However, BB153 was recently identified in marine mammals and fish from North America and Northern Europe (von der Recke and Vetter, 2008; Gieron et al., 2010).

This paper aims to provide new data on BFR contamination levels and patterns and the geographical distribution of BFRs in the marine flatfish Solea solea L. collected from main nursery zones along the French coast, with some emphasis on non-PBDE BFRs. As relatively little data is available on the levels of these latter compounds in European marine environments, this paper aims to provide reference data for French coasts, hence facilitating the future monitoring of these compounds. A special attention was devoted to examine the relationships between contamination levels and fish biological characteristics. To our knowledge, such detailed data about fish contamination by BFRs in French coastal areas has not been published to date. 


\section{Materials and Methods}

\subsection{Sample collection}

Fish samples were collected in 2007, 2008 and 2009 in the same season (autumn) from 4 main nursery zones: the Seine estuary in the English Channel, the Vilaine estuary, the Pertuis Breton and Pertuis of Antioche in the Bay of Biscay on the Atlantic Coast (Fig. 1). Three sampling zones were investigated in the Seine estuary: zone A (outer estuary), B (intermediate) and C (inner). Fish were collected at dawn using a benthic fish trawl. Each fish was individually sized and weighed immediately after collection and stored at $-20^{\circ} \mathrm{C}$ until further handling. Age determination was conducted on selected fish by otolith reading, and only juvenile fish of age group 1 were retained for BFR analysis.

\subsection{Standards and reagents}

The solvents (dichloromethane (DCM), n-hexane, toluene, acetone) used for our analyses were of trace analysis grade and supplied by SDS (France). Polystyrene gel beads Bio-Bead S-X3 (200-400 Mesh) were supplied by Bio-Rad Laboratories Inc. (USA). Silica gel (100-200 Mesh) and aluminium oxide (90 standardized) were supplied respectively by Sigma Aldrich (Germany) and Merck (Germany). Standard solutions used for calibration (BFR-CS1 to CS5), recovery surrogates added before extraction (BFR-LCS) and internal standard solution added before injection (BFR-ISS), were obtained from Wellington Laboratories Inc. (Ontario, Canada). The commerciallyavailable technical mixture Bromkal 70-5 DE was obtained from CIL Inc. (MA, USA), and Bromkal 79-8 DE and FR-300 BA were obtained from AccuStandard ${ }^{\circledR}$ Inc. (CT, USA).

\subsection{Sample preparation}

All fish samples were dissected in a clean laboratory (low dust and positive pressure) under a hood. Because only small differences between sexes were observed at this life-stage, males and females were not separated for pooling purposes. Each sample comprised 8 to 17 pooled individuals of similar age, and replicate pools ( $n=2$ to 3 ) were included at each sampling site when enough fish were available. All muscle (without skin) and liver were collected from each fish.

The total amount of extractable lipids was determined gravimetrically in muscle and liver in a separate extraction, using a mixture of acetone and hexane $(80 / 20 \mathrm{v} / \mathrm{v})$.

Tissue samples were homogenized, freeze-dried and spiked with a solution of labelled recovery standards before extraction. LCS solution, which included twenty ${ }^{13} \mathrm{C}$-labelled compounds (BDE-3, -15, -28- -47, -77, -99, -100, -126, -153, -154, -169, -183, -197, 205, -207, -209, HBB, BB-153, BTBPE, DBDPE), was added to each sample and each blank before extraction. BFR chemical analyses were conducted on 4 to 10 grams dry weight ( $\mathrm{dw}$ ) of muscle and on 0.2 to 0.8 grams $\mathrm{dw}$ of liver. The detailed analytical procedure was published previously (Johansson et al., 2006; Munschy et al., 2008). Extraction was done with DCM using Accelerated Solvent Extraction (ASE, Dionex Corp., USA). The extracts were cleaned on a gel permeation chromatography glass column (460 mm x $26 \mathrm{~mm}$ ) filled with styrene-divinylbenzene (Bio-beads S-X3) eluted 
with DCM, fractionated on a silica and alumina column and treated with concentrated sulphuric acid followed by several rinses with iso-octane. Extracts were further fractionated using a high-performance liquid chromatography (HPLC) system equipped with a nitrophenylpropylsilica column (Nucleosil, 5- $\mu \mathrm{m}$ particles, $250 \times 4.6 \mathrm{~mm}$, Interchim, France). Prior to injection, a BFR-ISS solution, containing the ${ }^{13} \mathrm{C}$-labelled BDE-79, BDE-139, BDE-180 and BDE-206 used as internal standards, was added to each sample.

\subsection{Instrumental analysis}

BFR analyses were performed using High Resolution Gas Chromatography - High Resolution Mass Spectrometry (HRGC-HRMS) with an AutoSpec Ultima (Waters, Manchester, UK) operated in electronic impact (EI) ionisation mode at a minimum resolution of 10,000 in the selected ion monitoring (SIM) mode. The technical mixtures Bromkal 70-5 DE, Bromkal 79-8 DE and FR-300 BA were also analysed by HRMS. The HRMS was interfaced with a Hewlett-Packard (Palo Alto, CA, USA) 6890 gas chromatograph. All analyses were done using two different chromatographic columns: a $15 \mathrm{~m}$ DB-1 column (J\&W Scientific, CA, $0.25 \mathrm{~mm}$ i.d., $0.10 \mu \mathrm{m}$ film thickness) and a $30 \mathrm{~m} \mathrm{DB}-1$ (J\&W Scientific, CA, $0.25 \mathrm{~mm}$ i.d., $0.10 \mu \mathrm{m}$ film thickness). The temperature programmes used were i) $100{ }^{\circ} \mathrm{C}$ for $2 \mathrm{~min}$., $25^{\circ} \mathrm{C} / \mathrm{min}$. to $250{ }^{\circ} \mathrm{C}, 1.5{ }^{\circ} \mathrm{C} / \mathrm{min}$. to 260 ${ }^{\circ} \mathrm{C}, 25^{\circ} \mathrm{C} / \mathrm{min}$. to $325^{\circ} \mathrm{C}$, hold $7 \mathrm{~min}$., helium at $1 \mathrm{ml} / \mathrm{min}$. for the $15 \mathrm{~m}$ column; ii) 100 ${ }^{\circ} \mathrm{C}$ for $2 \mathrm{~min}$., $40{ }^{\circ} \mathrm{C} / \mathrm{min}$. to $180{ }^{\circ} \mathrm{C}, 15^{\circ} \mathrm{C} / \mathrm{min}$. to $240{ }^{\circ} \mathrm{C}, 4^{\circ} \mathrm{C} / \mathrm{min}$. to $325^{\circ} \mathrm{C}$, hold 5 min., helium at $0.8 \mathrm{ml} / \mathrm{min}$. for the $30 \mathrm{~m}$ column. Thirty-eight PBDE congeners ranging from dibrominated to decabrominated congeners were looked for in all samples, i.e., BDE-7, -10, -15, -17, -28, -30, -47, -49, - 66, -71, -77, -85, -99, -100, -119, -126, -138, 139, -140, -153, -154, -156, -169, -171, -180, -183, -184, -191, -196, -197, -201, -203, $204,-205,-206,-207,-208$, and -209 . The results obtained on the longer column were chosen for most compounds, except for octa-, nona- and decabrominated congener results, which were generally taken from the $15 \mathrm{~m}$ column. However, the results obtained from both columns were very similar for most compounds, including for BDE209. The congeners which showed different results on the $30 \mathrm{~m}$ and the $15 \mathrm{~m}$ columns were BDE-49 (poorly resolved from BDE-71 on the $15 \mathrm{~m}$ column), BDE-119 and BDE154 , both of which were better-resolved on the $30 \mathrm{~m}$ column. Injections of $1 \mu \mathrm{l}$ were done in splitless mode at $280{ }^{\circ} \mathrm{C}$ using a CTC Combi-Pal autosampler (CTC Analytics, Zurich, Switzerland). The GC/MS interface was maintained at $250{ }^{\circ} \mathrm{C}$, and the ion source at $280{ }^{\circ} \mathrm{C}$. Single Ion Recording (SIR) calibration was achieved using perfluorokerosene at the start of each sequence run. Resolution was checked regularly (i.e., after each sample) during each sequence run using the resolution check tool. The various congeners were monitored using the two most abundant isotopes representing the molecular peak $[\mathrm{M}]^{+}$or $[\mathrm{M}-2 \mathrm{Br}]^{+}$, depending on the congeners. In order to optimise sensitivity and resolution conditions, BTBPE was analysed for its base peak (356.7948) in a single, separate run. Peak identification was performed using retention times, comparison to authentic standards and via the isotopic ratio. Quantification was achieved using the isotopic dilution method. Congeners below the instrumental limits of quantification (LOQ), or with a poor isotopic ratio, were not taken into consideration in our results. 


\subsection{Quality Assurance / Quality Control}

Quality Assurance / Quality Control procedures were followed during each sequence analysis. Blanks were processed within each sample batch (generally 8-12 samples) throughout the whole analytical procedure. Samples were processed in the laboratory in a clean, low dust atmosphere and under positive pressure, and windows were UVprotected. Despite the ultra-clean conditions, BDE-209 was still detected in the blank. BDE-209 concentrations in fish were hence corrected versus blanks using the median value found in the procedural blanks $(5.7 \mathrm{pg} / \mu \mathrm{l})$. Labelled standard recoveries were between $75 \pm 11 \%$ and $108 \% \pm 25 \%$ for PBDEs, and between $74 \% \pm 30 \%$ and 111 $\% \pm 36 \%$ for non-PBDE BFRs (mean values \pm standard deviation, $\mathrm{n}=70$ ).

Limits of Detection (LODs), calculated for each sample by taking into account the injection volume, the volume of the concentrated extract before injection and the extracted sample mass, were between $0.002 \mathrm{pg} / \mathrm{g} \mathrm{ww}$ and $0.054 \mathrm{pg} / \mathrm{g}$ ww in muscle, and between $0.048 \mathrm{pg} / \mathrm{g}$ ww and $1.1 \mathrm{pg} / \mathrm{g}$ ww in liver (median values, $\mathrm{n}=35$ ), depending on the congeners. BDE-209 LODs were slightly higher, i.e. $0.56 \mathrm{pg} / \mathrm{g} \mathrm{ww}$ and $7.8 \mathrm{pg} / \mathrm{g} \mathrm{ww}$ in muscle and liver, respectively. LODs calculated for the non-BFR compounds were in the 0.006-0.17 pg/g ww and 0.10-4.2 pg/g ww ranges in muscle and liver, respectively.

Analyses of certified material WMF-01 (Wellington laboratories) were regularly included in sample sequences. This material is a freeze-dried fish tissue containing the following congeners at certified reference values: BDE-28, BDE-47, BDE-99, BDE-100, BDE153, BDE-154, BDE-183 (provisional value), at concentrations of 0.5 to $123 \mathrm{ng} / \mathrm{g} \mathrm{dw}$. The results were within the certified ranges for all congeners.

In order to check our method performance with low contamination levels on marine biota, the laboratory routinely participates in the QUASIMEME (Quality Assurance of Information for Marine Environmental Monitoring in Europe) intercomparison exercises for PBDEs, and obtains satisfactory $Z$ scores, i.e. generally between -2 and +2 . Although most exercises were done using GC-LRMS-ECNI (low resolution MS-electron capture negative ionisation mode), HRMS was used in 2010 and gave very good results.

Non-PBDE BFRs were analysed using the same QA/QC protocols as for PBDEs, with the exception of certified material analysis, as none was available for the analysed compounds.

\subsection{Data analysis}

Different statistical tests were used to analyse the results obtained during this study using Statistica v7.1 software (StatSoft Inc., USA). Correlations (e.g. between lipid content in muscle and liver, lipid content and PBDE concentrations in selected tissue, and PBDE concentrations in liver and muscle) were tested using simple linear regression coefficients. Comparisons of Fulton's K condition index, liver somatic index (LSI), and PBDE concentrations at the various sites over the 3-year period were performed using the Wilcoxon-Mann-Whitney or Kruskal-Wallis tests. Unless specifically mentioned, the chosen significance level was $\alpha=0.05$. 


\section{Results and Discussion}

\subsection{Fish biometry and condition indices}

A total of 617 fish samples were collected from the various sites during our 3-year study, including 442 fish which were analysed for BFRs. In order to achieve a better significance level, biometry and condition indices were evaluated on the fish as a whole. In most cases, the same results were obtained with both sets of data. The results are presented in the Supplementary material (Table S1).

Fulton's condition index $\mathrm{K}$ was used as an indicator of the general well-being of the fish (Gilliers et al., 2004). $\mathrm{K}$ was calculated as $\mathrm{K}=100\left(\mathrm{~W} \times \mathrm{L}^{3}\right)$, whereby $\mathrm{W}$ is total weight (g) and $L$ is total length $(\mathrm{cm})$. Total weight and total length were used instead of eviscerated fish weight and standard length, as the latter were not available for all fish. When eviscerated fish weight and standard length were available, $\mathrm{K}$ was calculated using both values and the same conclusions were obtained. $\mathrm{K}$ indices were between $0.71 \pm 0.08$ and $0.88 \pm 0.13$ (Table S1). Notwithstanding the year, $\mathrm{K}$ indices were significantly lower in fish from the Pertuis of Antioche than in fish from the other sites. Fish from the inner part of the Seine estuary (ZC) generally showed significantly lower $\mathrm{K}$ indices than fish from the intermediate $(\mathrm{ZB})$ and outer $(\mathrm{ZA})$ areas. The highest $\mathrm{K}$ indices were generally recorded in samples from the Seine estuary. $K$ indices in fish sampled in 2007 were generally significantly higher than those in fish sampled in 2009. Similarly, fish lengths were significantly higher in 2007 versus 2009, and highest in the Seine estuary. $\mathrm{K}$ indices were positively correlated with lipid content in both muscle $(r=$ $0.49, p<0.05)$ and liver $(r=0.60, p<0.001)$.

The Liver Somatic Index (LSI) was used as an indicator of fish physiological state and calculated as $\mathrm{LSI}=(\mathrm{LW} / \mathrm{BW}) \times 100$, whereby LW and BW are liver and body weights respectively (Grant and Brown, 1999). LSI values were between $0.56 \pm 0.17$ and $0.97 \pm$ 0.25 (Table S1). Contrary to our $\mathrm{K}$ index observations, no significant general trend was highlighted in terms of years and sites. Nonetheless, in the Pertuis of Antioche, Pertuis Breton and ZC of the Seine estuary, LSIs were significantly lower in 2008 than in 2007, whereas no differences were noted in the Vilaine estuary during the 3-year study.

Total extractable lipids were determined in each pooled sample of muscle and liver. Lipid content was between $0.08 \%$ and $0.49 \%$ ww in muscle, and between $0.57 \%$ and $12.4 \% \mathrm{ww}$ in liver (Table S1). These values are lower than those reported in situ in sole from other coastal areas, although the comparison was not straightforward, as fish biological parameters (size, age, sex) were not systematically available in the literature (Ikonomou et al., 2002; Voorspoels et al., 2003; Bragigand et al., 2006). Although lipid content varied widely, significant differences were not generally observed with regards to the site and year, mainly because the number of values was limited. The only significant differences found were in lipid content in both muscle and liver in 2007 and 2009, and in liver in 2008 and 2007, in samples from the Seine estuary: a higher lipid content was systematically observed in samples collected in 2007. Lipid content in muscle and liver was significantly correlated (linear relation, $r=0.61, p<0.001$ ). No correlation was found between LSI and lipid content, or LSI and K. 


\subsection{PBDE contamination levels}

Among the analysed congeners, fourteen were identified in samples at levels above the LODs. These included BDE-17, -28, -47, -49, -66, -99, -100, -119, -153, -154, -183, $-184,-197$ and -201 . Among these, only 5 congeners were not detected in all samples: BDE-119 (97\% of samples), BDE-99 (94\%), BDE-184 (89\%), BDE-201 (89\%) and BDE-197 (91 \%). Two other congeners (BDE-85, BDE-140) were also detected, but only in the most contaminated samples (i.e. in samples from the Seine estuary and in liver samples); they were not therefore taken into account in the sum of detected congeners.

PBDE concentrations (sum 14 BDEs) in the muscle and liver of fish collected from the various sampling sites over the 3-year period are presented in Fig. 2. PBDE concentrations were positively correlated with lipid content in both muscle $(r=0.42, p<$ $0.05)$ and liver $(r=0.85, p<0.0011)$. Hence, PBDE concentrations were also expressed in relation to lipid content. Concentrations ranged from $0.01 \mathrm{ng} / \mathrm{g} w \mathrm{w}$ to 0.16 $\mathrm{ng} / \mathrm{g}$ ww $(2.8 \mathrm{ng} / \mathrm{g}$ lw to $82.5 \mathrm{ng} / \mathrm{g} \mathrm{lw})$ in muscle, and from $0.07 \mathrm{ng} / \mathrm{g}$ ww to $2.8 \mathrm{ng} / \mathrm{g} \mathrm{ww}$ (3.3 ng/g Iw to $53.2 \mathrm{ng} / \mathrm{g} \mathrm{Iw}$ ) in liver. Concentrations in ww were 12 to 20 times higher in liver than in muscle, depending on the congeners; liver/muscle ratio concentrations showed a significant linear correlation with the congener number of bromine atoms (and $\log \mathrm{K}_{\mathrm{ow}}$ ), suggesting a lipid partitioning process of PBDEs in relation to their log $\mathrm{K}_{\mathrm{ow}}$. When normalized to lipid content, concentrations were in the same range in both muscle and liver: liver/muscle concentration ratios were between 0.9 and 1.6 (median values) depending on the congener.

PBDE concentrations (expressed in $\mathrm{ng} / \mathrm{g} w \mathrm{w}$ ) in muscle were significantly correlated with liver concentrations $(r=0.94, p<0.001)$. Concentrations in both muscle and liver were positively correlated with total length $(r=0.74$ and 0.70 , respectively, $p<0.001$, all data). PBDE concentrations in samples from the Seine estuary were positively correlated with $\mathrm{K}$ indices $(r=0.84$ and 0.78 in muscle and liver, respectively, $p<$ 0.001 ), whereas this relationship was not highlighted in samples from the other sites. No correlation was found between PBDE concentrations in muscle or liver and LSI.

Sole samples from the Seine estuary (English Channel) showed the highest concentrations in all years (either in ww or Iw), while samples from the Atlantic coast (Vilaine, Pertuis Breton and Pertuis of Antioche) exhibited lower and similar values. Various marine species from the Seine estuary have already been shown to be highly contaminated due to major industrial and urban activity in the associated catchment area (Bragigand et al., 2006; Johansson et al., 2006; Bodin et al., 2007). PBDE concentrations in muscle (in $\mathrm{ng} / \mathrm{g} \mathrm{ww}$ ) in samples from the Seine estuary showed significantly lower levels in 2009 than in 2007 and 2008 at all sampling sites. These differences were also observed and significant in liver. The lower concentrations observed in 2009 coincide with a lower average water flow $\left(356 \mathrm{~m}^{3} / \mathrm{sec}\right.$ in 2009 , versus $505 \mathrm{~m}^{3} / \mathrm{sec}$ and $525 \mathrm{~m}^{3} / \mathrm{sec}$ in 2007 and 2008, respectively). As shown in other studies, flooding and higher river flows tend to increase contaminant loads in estuarine zones (Lair et al., 2009; Zhao et al., 2011); this increase has already been observed in sentinel species (Johansson et al., 2006; Munschy et al., 2008). The lower PBDE concentrations observed in 2009 are also associated with a lower K index, length and lipid content, hence indicating globally poorer fish health. Although higher contamination levels were expected in zone $C$, located further upstream in the estuary, fish from this zone did not show higher contamination levels: in 2009, levels were similar in the three study zones; in 2008 and 2007, zone C showed less contamination 
than zone $B$ and zone $A$ (not significant). This tends to indicate that the age-1 group is not strictly bound to a limited zone inside a specific nursery.

Samples originating from Pertuis of Antioche and Pertuis Breton did not show any significant differences depending on the site or year. Samples from the Vilaine estuary showed slightly higher concentrations in 2008 versus 2007 and 2009, and the difference between 2008 and 2009 was significant in both muscle and liver. Contrary to our observations in the Seine estuary, these differences in PBDE concentrations could not be explained by differences in river flows, which were $79 \mathrm{~m}^{3} / \mathrm{sec}, 86 \mathrm{~m}^{3} / \mathrm{sec}$ and 69 $\mathrm{m}^{3} / \mathrm{sec}$ in 2007, 2008 and 2009, respectively. The Vilaine estuary is much smaller than the Seine estuary and drains a less industrialized and urbanized catchment area. Our results would tend to indicate that major sources of PBDE contamination in fish in the Vilaine estuary do not originate from river inputs.

In addition to the 14 main congeners, BDE-209 was detected at levels exceeding those found in the procedural blank in a limited number of muscle samples, at levels between $7 \times 10^{-4} \mathrm{ng} / \mathrm{g} \mathrm{ww}$ and $0.01 \mathrm{ng} / \mathrm{g} \mathrm{ww}(0.18-5.27 \mathrm{ng} / \mathrm{g} \mathrm{Iw})$ in muscle, and in two liver samples at $0.17 \mathrm{ng} / \mathrm{g} \mathrm{ww}$ and $0.19 \mathrm{ng} / \mathrm{g} \mathrm{ww}$ (3.9 and $6.0 \mathrm{ng} / \mathrm{g} \mathrm{lw}$ ). Despite its high molecular size, BDE-209 bioavailability for biota is provenly low. However, low uptake and active metabolism has been found to occur in fish at various extents depending on the species. Previously-published studies have reported BDE-209 debromination into lower brominated congeners - mainly hexa- to nona-BDEs - in juvenile carp (Cyprinus carpio), rainbow trout (Oncorhynchus mykiss) and common sole (Solea solea L.) (Kierkegaard et al., 1999; Stapleton et al., 2004a, 2006; Tomy et al., 2004; Munschy et al., 2011).

\subsection{Comparison of PBDE levels in Europe}

BDE-47 is the most abundantly-found PBDE congener in biota and, as a result, data on its concentrations is fairly widely-available in the literature. BDE-47 concentrations were thus taken into account in order to compare our results with those of other studies. As PBDE contamination levels and patterns can vary widely according to species and habitat, we focused primarily on studies on benthic or bottom feeder fish from estuarine or coastal areas. Comparison was not always straightforward, as detailed data was not systematically available. Moreover, fish age and gender for adult specimens were not systematically reported in the published results. In addition, we focused our comparison on studies relative to Europe, as levels found on other continents such as North America or Asia can show major variations due to the different quantities of BFRs used (Hites, 2004, Law et al., 2008; Shaw and Kannan, 2009). Our results comparison is presented in Table 1 . In this study, BDE-47 concentrations in age-1 sole varied between $0.002 \mathrm{ng} / \mathrm{g} \mathrm{ww}$ and $0.05 \mathrm{ng} / \mathrm{g} \mathrm{ww}$, or 0.5 $\mathrm{ng} / \mathrm{g} \mathrm{Iw}$ and $29.9 \mathrm{ng} / \mathrm{g} \mathrm{lw}$ in muscle, and between $0.02 \mathrm{ng} / \mathrm{g} \mathrm{ww}$ and $0.87 \mathrm{ng} / \mathrm{g} \mathrm{ww}$, or $0.9 \mathrm{ng} / \mathrm{g} \mathrm{Iw}$ and $18.4 \mathrm{ng} / \mathrm{g}$ lw in liver. Data on PBDE contamination in marine benthic biota along French coasts remains scarce and recent: the results published by Bragigand et al. (2006) reported BDE-47 levels in the muscle of sole (Solea solea) collected from the Loire estuary to be between $0.09 \mathrm{ng} \mathrm{g}^{-1} \mathrm{ww}$ and $0.39 \mathrm{ng} \mathrm{g}^{-1} \mathrm{ww}$; these concentrations were far higher than those found in our study in samples from both the English Channel and the Atlantic. Globally, the concentrations found in our study in sole samples collected from French coasts were in the lower range of those reported in other European locations (Table 1). The levels we found were comparable 
to those reported in fish from European high mountain lakes or Antarctica (Vives et al., 2004; Blais et al., 2006; Borghesi et al., 2009). The fairly low concentrations determined in our study may be due to the fact that the samples were restricted to age1 specimens, whereas the other studies generally related to older fish. Furthermore, our fish were collected from coastal zones affected to various extents by contaminant inputs due to human activity, but not directly influenced by a close source, as was the case in the various other studies mentioned in Table 1.

In addition to BDE-47, BDE-209 levels were also compared with data from the literature. In view of the analytical challenge involved in obtaining accurate results, BDE-209 is seldom reported in biota, especially in coastal marine fish. Voorspoels et al. (2003) found this congener in the liver of various fish species from the North Sea and Scheldt estuary at levels ranging from 3.4 to $37.2 \mathrm{ng} / \mathrm{g} \mathrm{ww}$, i.e. several orders of magnitude higher than the levels determined in our study. Other published results obtained on benthic fish are in the range of those found in our study. For example, concentrations of $0.06-0.07 \mathrm{ng} / \mathrm{g} \mathrm{ww}$ and 0.006 and $0.020 \mathrm{ng} / \mathrm{g}$ ww were reported in benthic fish from Norway (Berge et al., 2006; Sormo et al., 2009). Lepom et al. (2006) found BDE-209 above the LOQ in only one dab liver sample from the North Sea, at $0.05 \mathrm{ng} / \mathrm{g} \mathrm{ww}$. Regarding pelagic species, concentrations of 0.04-0.11 ng/g ww were determined in herring from the Baltic Sea, although remarkably higher levels (2.6 and $16.4 \mathrm{ng} / \mathrm{g} \mathrm{ww}$ ) were reported in two samples (Roots et al., 2010). In Atlantic and polar cod from the Norwegian North-East Atlantic, BDE-209 was found at 0.27-0.64 ng/g lw, although the results showed high standard deviations (Jenssen et al., 2007). Gomara et al. (2006) found BDE-209 at $<0.0002-0.01 \mathrm{ng} / \mathrm{g} \mathrm{ww}$ in various fish from the Spanish market.

\subsection{PBDE contamination patterns and potential origins}

Among the identified PBDEs, BDE-47 was the predominant congener in most samples, accounting for $32 \%$ of the sum of the 14 BDEs in muscle (mean pattern, Fig. 3). The PBDE mean congener pattern was similar in liver samples. BDE-47 is reportedly the most abundant congener in fish worldwide, irrespective of levels, species, and sampling sites (de Wit, 2002; Watanabe and Sakai, 2003; Hites, 2004; Law et al., 2006b). Abundance of the other main congeners was BDE-100 - BDE-154 > BDE-49 > BDE-99 > BDE-28 > BDE-153 and > BDE-183. These eight congeners represent, on average, $95 \%$ of the sum of the 14 congeners in both liver and muscle. Significant differences were found in relative concentrations of BDE-17, -28, -100, -119, -154 and 197 in samples from the Seine estuary and Atlantic, and the contribution of these congeners with the exception of BDE-100 was higher in samples from the Atlantic than from the Seine estuary.

Congener distribution in biological samples has often been compared to the composition of the Pentabromodiphenyl ether (PentaBDE) commercial product (Boon et al., 2002; Law et al., 2003, Rayne et al., 2003; Ikonomou et al., 2006). Results from HRMS analysis of PBDE commercial mixtures (Supplementary material, Table S2) indicate that Bromkal 70-5 DE (technical pentaBDE) contains a majority of penta- (58.6 $\%$ ) and tetra-brominated (32.9\%) congeners, whereas Bromkal 79-8 DE (technical octaBDE) contains BDE-209 (35\%), nona- (29.5\%), octa- (21\%) and hepta-BDEs (14.4\%). FR-300 BA (technical decaBDE) contains mainly BDE-209 (93\%). These results coincide with previous reports (Alaee et al., 2003; La Guardia et al., 2006), although one main difference was found for BDE-47 in Bromkal 70-5 DE, which was 
slightly lower in our case. It is interesting to note that BDE-209 was found in fairly high proportions (35 \%) in the European Bromkal 79-8 DE formulation versus the American DE-79 from Great Lakes Chemical Corp., Indiana (BDE-209 at $1.3 \%$, La Guardia et al., 2006). The different technical deca- mixtures analysed in previous studies (i.e., Saytex 102E and Bromkal 82-ODE, La Guardia et al., 2006) systematically showed BDE-209 to be the predominant congener. The mean pattern determined in sole in our study (Fig.4) shows a greater similarity with the pentaBDE technical mixture than with the octaBDE or decaBDE technical mixtures, although a lower proportion of penta-BDE congeners was found in sole versus the technical pentaBDE mixture (26\% and $59 \%$, respectively). However, the patterns observed in sole are a result of source exposure, bioavailability, uptake efficiency and potential metabolism of the various congeners; a direct comparison of environmental patterns and technical mixtures is therefore complex, except in the case of point source contamination (Dodder et al., 2002).

The accumulation pattern we observed in sole differs somewhat from other studies carried out on other marine fish species. For example, BDE-99 has been found in various fish species, including sole, at a higher relative level than in our study (i.e., $4 \%$ of the sum of the 14 congeners) (Boon et al., 2002; Hites, 2004; Bragigand et al., 2006; Ikonomou et al., 2006; Shaw and Kannan, 2009). Low BDE-99 abundance has been reported in various fish species from China (Meng et al., 2008) and Japan (Akutsu et al., 2001), similarly to our findings, whereas BDE-99 was not detected at all in feral carp from the Llobregat River in Spain (Labandeira et al., 2007). The BDE-99/BDE-100 ratio is commonly used as an indicator of the metabolic capacity of organisms, with a low ratio indicating a high metabolic capacity. In our study, this ratio was between 0.10 and 0.57 (median value of 0.18 , calculated on all samples) in muscle samples, i.e. similar to previously-published results (Christensen et al., 2002; Voorspoels et al., 2003; Meng et al., 2008; Li et al., 2010). This ratio was 0.16 (median value) in liver samples, although it varied fairly widely between samples (between 0.06 and 1.94). These results suggest that sole have a high BDE-99 metabolism capability. The BDE47/BDE-99 ratio has also been suggested as an indicator of the capacity of organisms to metabolise BDE-99, with a high value indicating a high metabolic capacity. In our study, the median value of this ratio was 8.3 in muscle and 9.3 in liver. This ratio could also reflect different patterns of exposure: BDE-47/BDE-99 was found to be lower in fish from North America and in sole from Bohai Sea, China, i.e. a ratio of around 2 (Hites, 2004; Tian et al., 2010). Variations in this ratio could also be influenced by exposure time, with lower values reflecting more recent exposure (Roosens et al. 2010).

Conversely, BDE-49 concentrations were fairly high (11-12 \% in muscle and liver) in comparison to previous results reported in English sole (Ikonomou et al., 2002; 2006). In an experimental study previously conducted on the same species, we hypothesized that BDE-99 was debrominated into BDE-49, and demonstrated a high metabolism rate leading to higher concentrations of BDE-49 versus BDE-99, to which the fish were exposed (Munschy et al., 2011). In the present study, the ratio of BDE-49 to BDE-99 was 3.0 (median value calculated on all samples) in muscle and 3.7 in liver. The low levels of BDE-99 and high levels of BDE-49 reported here in the wild therefore appear to be consistent with our previous experimental work. Globally, the results obtained in our study tend to indicate that sole has a higher BDE-99 metabolism capability than other fish.

Another striking difference is that BDE-154 was found at particularly high levels in our samples, representing, on average, $21 \% \pm 7 \%$ in muscle and $20 \% \pm 8 \%$ in liver (mean values \pm standard deviations calculated on the sum of the 14 congeners in all 
samples). A high proportion of BDE-154 could be attributed to exposure and / or metabolic processes. As this phenomenon has already been highlighted in various fish species, BDE-154 could be the result of BDE-209 or BDE-183 metabolic degradation (Kierkegaard et al., 1999; Stapleton et al., 2004a,b). However, no evidence of BDE-209 degradation into BDE-154 in sole was found in our previous experimental study (Munschy et al., 2011). The high proportion of BDE-154 in sole may also be the result of exposure to this congener originating from degradation processes other than metabolism in fish, such as photolytic degradation or anaerobic degradation of octa- or decabromo diphenyl ether mixtures (Söderström et al., 2004; Gaul et al., 2006; He et al., 2006; Zeng et al., 2010). The presence of BDE-154 at high levels in fish could also be attributed to exposure to various sources: BDE-154, BDE-153 and BDE-183, together with other heptabromo- congeners, have already been linked to local inputs from industrial activities or waste discharges and found to be high in fish (Rice et al., 2002; Eljarrat et al., 2004). Peng et al. (2007) found BDE-154 and BDE-183 to be the predominant congeners in various fish species from Taiwan, related to octa-BDE usage. However, in our study, BDE-154 was the only significant high-brominated congener found in the fish and could not therefore be attributed solely to the use of a high-brominated PBDE mixture. In addition, BDE-154 was relatively prevalent in all nursery zones, which would rule out the influence of local sources.

In addition, two other congeners identified in sole could originate from BDE-209 metabolism: BDE-140 and BDE-201 have been reported on the basis of in vitro or in vivo laboratory experiments on different fish species (Tomy et al., 2004; Stapleton et al., 2006).

\subsection{Non-PBDE BFR contamination levels}

Non-PBDE BFRs, namely BTBPE, DBDPE, HBB and BB-153, were also identified, but at very low concentrations, i.e., lower than those of PBDEs. Levels in numerous samples were below the LODs. The concentrations of these compounds in sole samples are presented in Table 2.

BTBPE mean concentrations in sole muscle and liver were between $0.2 \mathrm{pg} / \mathrm{g} \mathrm{ww}$ and $0.7 \mathrm{pg} / \mathrm{g} \mathrm{ww}$ (or $0.08 \mathrm{ng} / \mathrm{g} \mathrm{Iw}$ and $0.31 \mathrm{ng} / \mathrm{g} \mathrm{Iw}$ ), and between $5.3 \mathrm{pg} / \mathrm{g} \mathrm{ww}$ and 40.2 $\mathrm{pg} / \mathrm{g}$ ww (or $0.17 \mathrm{ng} / \mathrm{g}$ Iw and $4.1 \mathrm{ng} / \mathrm{g} \mathrm{Iw}$ ), respectively. Concentrations in samples from the Seine estuary were in the same range as those found in samples from the Atlantic, suggesting that BTBPE origin was not directly related to high anthropogenic activity in the Seine estuary. Concentrations in sole were three orders of magnitude lower than the mean concentrations in the muscle of various fish species from Lake Winnipeg, Canada, which were between 0.13 and $0.95 \mathrm{mg} / \mathrm{g}$ Iw (Law et al., 2006a). In lake trout from Lake Ontario, Canada, BTBPE concentrations increased between 1979 and 1993, then decreased to around $1.6 \mathrm{ng} / \mathrm{g}$ Iw up to 2004 (Ismail et al., 2009). In southern China, BTBPE was found at levels of between $<0.012 \mathrm{ng} / \mathrm{g} \mathrm{lw}$ and $0.105 \mathrm{ng} / \mathrm{g}$ Iw in the muscle of freshwater fish collected from an electronic waste processing area (Shi et al., 2009), whereas Wu et al. (2010) reported much higher values (i.e. 1.71-518 $\mathrm{ng} / \mathrm{g}$ Iw).

DBDPE mean concentrations in sole muscle samples were between $0.9 \mathrm{pg} / \mathrm{g} \mathrm{ww}$ and $1.9 \mathrm{pg} / \mathrm{g} \mathrm{ww}$ (or 0.28 and $1.13 \mathrm{ng} / \mathrm{g} \mathrm{lw}$ ), and between < LOD and $14.2 \mathrm{pg} / \mathrm{g} \mathrm{ww}$ (or < LOD and $1.33 \mathrm{ng} / \mathrm{g} \mathrm{Iw}$ ) in liver. These concentrations were far lower than those reported in various fish species from Lake Winnipeg, Canada, (0.08-1.01 mg/g lw 
range, Law et al., 2006a), or from an electronic waste recycling site (up to $338 \mathrm{ng} / \mathrm{g} \mathrm{Iw}$, Wu et al., 2010). As for BTBPE, concentrations were in a similar range in samples from all areas, suggesting that DBDPE in sole does not originate directly from local or regional inputs.

HBB levels were between $0.9 \mathrm{pg} / \mathrm{g} \mathrm{ww}$ and $2.8 \mathrm{pg} / \mathrm{g} \mathrm{ww}$ (or 0.5 and $1.4 \mathrm{ng} / \mathrm{g} \mathrm{Iw}$ ) in muscle, and between $3.9 \mathrm{pg} / \mathrm{g} \mathrm{ww}$ and $54.3 \mathrm{pg} / \mathrm{g}$ ww in liver (or 0.1 and $5.3 \mathrm{ng} / \mathrm{g} \mathrm{lw}$ ). Contrary to our observations on PBDEs, slightly higher levels were found in samples collected on the Atlantic coast (Vilaine estuary, Pertuis of Antioche and Pertuis Breton). The levels determined in our study were far below those reported in freshwater fish in China, i.e., in the 680-2451 ng/g lw range, although the fish were collected from an electronic waste recycling site (Wu et al., 2010).

BB-153 mean concentrations were in the $0.1-3.0 \mathrm{pg} / \mathrm{g} \mathrm{ww}(0.05-1.66 \mathrm{ng} / \mathrm{g} \mathrm{Iw})$ range in muscle, and in the 1-56.2 pg/g ww (0.06-1.74 ng/g lw) range in liver. The highest levels were revealed in samples from the Seine estuary. Although BB-153 is no longer produced, its concentrations in samples from the Seine estuary were higher than those of the other non-PBDE BFRs. Gieron et al. (2010) reported concentrations of BB-153 in the $<0.90-179 \mathrm{pg} / \mathrm{g}$ ww range in fish from the Baltic and North seas.

Concentrations of the above-mentioned novel BFRs were similar to those determined in sole muscle collected from the same areas in 2003 and 2004 (Munschy et al., 2007). Despite restricted PBDE use in Europe and the expected use of DBDPE and BTBPE as replacement chemicals, no increase in their concentrations in sole was observed during the study years. However, insufficient data was available at levels above the LODs to allow a meaningful trend study.

\section{Conclusions}

This study reports the results of an extensive investigation into BFRs in age-1 common sole from France's main coastal nurseries. Both classic PBDEs and novel BFRs were investigated, hence providing reference values on juvenile benthic fish contamination along French coasts. Fourteen PBDE congeners were identified in the majority of samples. Among them, BDE-47, BDE-100, BDE-154, BDE-49, BDE-99, BDE-28, BDE153 and BDE-183 represented, on average, $95 \%$ of the sum of the 14 congeners in sole. PBDE concentrations in sole determined during our study were in the lower range of those reported in the literature in other European locations. The highest concentrations were found in fish from the Seine estuary. Lower PBDE concentrations, $\mathrm{K}$ indices and lipid contents were observed in this estuary in 2009, possibly in relation to a lower water flow. Nevertheless, no general evidence could be given of PBDE concentrations versus fish condition indices.

The identified PBDE contamination patterns and congener specific ratios suggest that sole have a high metabolic degradation capacity. In addition to BDE-99/BDE-100 and BDE-47/BDE-99 ratios, the BDE-99/BDE-49 ratio could be used to characterize the metabolism capability of organisms. In view of this, we believe that BDE-49 should be included in the list of priority PBDEs analysed in biota. 
BDE-209 was also detected, although in a limited number of samples. In addition, several congeners, possibly originating from BDE-209 debromination, were identified, suggesting that sole were exposed to BDE-209 and able to metabolise it.

Among the novel BFRs, BTBPE and DBDPE were identified in samples at lower concentrations than PBDEs. These compounds are marketed as alternatives to other brominated compounds. They are thus of particular interest with respect to future environmental monitoring. BB-153 and HBB, i.e. the other non-PBDE BFRs identified in this study, were also detected at low levels.

\section{Acknowledgments}

This research was funded by the "Agence Nationale pour la Recherche" in the framework of the "Vulnérabilité Milieux et Climat" project (ANR-06-PVULN-013). The authors would like to thank several people for their help in collecting the fish and determining fish age, in particular, Marie-Laure Bégout from Ifremer La Rochelle for supervising fish collection and ageing in Pertuis Breton and Pertuis of Antioche, and Sébastien Rochette from Agrocampus Rennes for fish collection in the Vilaine estuary. Thanks also to Olivier Le Pape from Agrocampus Rennes for his advice on ageing fish from the Vilaine estuary. We acknowledge Laura Valentine from "English Assistance for Industry" for the English corrections made to the manuscript.

\section{References}

Akutsu K, Obana H, Okihashi M, Kitagawa M, Nakazawa H, Matsuki Y, Makino T, Oda $\mathrm{H}$, Hori S. GC/MS analysis of polybrominated diphenyl ethers in fish collected from the Inland Sea of Seto, Japan. Chemosphere 2001; 44, 1325-1333.

Alaee M, Arias P, Sjodin A, Bergman A. An overview of commercially used brominated flame retardants, their applications, their use patterns in different countries/regions and possible modes of release. Environ Int 2003; 29, 683-689.

Ali N, Harrad S, Goosey E, Neels H, Covaci A. "Novel" brominated flame retardants in Belgian and UK indoor dust: Implications for human exposure. Chemosphere 2011; 83, 1360-1365.

Berge JA, Schlabach M, Fjeld E. BFR contamination of the marine environment around the city of Alesund, Norway. Organohalogen Compounds 2006; 68, 53-56.

Bethune C, Nielsen J, Julshamn K. Current levels of primary polybrominated diphenyl ethers (PBDEs) in Norwegian seafood. Organohalogen Compounds 2004; 66, 38143819.

Blais JM, Charpentié S, Pick F, Kimpe LE, Amand AS, Regnault-Roger C. Mercury, polybrominated diphenyl ether, organochlorine pesticide, and polychlorinated biphenyl concentrations in fish from lakes along an elevation transect in the French Pyrenees. Ecotox Environ Safe 2006; 63, 91-99.

Bodin N, Abarnou A, Fraisse D, Defour S, Loizeau V, Le Guellec AM, Philippon X. $\mathrm{PCB}, \mathrm{PCDD} / \mathrm{F}$ and PBDE levels and profiles in crustaceans from the coastal waters of Brittany and Normandy (France). Mar Pollut Bull 2007; 54, 657-668.

Boon JP, Lewis WE, Tjoen-A-Choy MR, Allchin CR, Law RJ, de Boer J, Ten HallersTjabbes CC, Zegers BN. Levels of polybrominated diphenyl ether (PBDE) flame retardants in animals representing different trophic levels of the North Sea food web. Environ Sci Technol 2002; 36, 4025-4032. 
Borghesi N, Corsolini S, Leonards P, Brandsma S, de Boer J, Focardi S. Polybrominated diphenyl ether contamination levels in fish from the Antarctic and the Mediterranean Sea. Chemosphere 2009; 77, 693-698.

Bragigand V, Amiard-Triquet C, Parlier E, Boury P, Marchand P, El Hourch M. Influence of biological and ecological factors on the bioaccumulation of polybrominated diphenyl ethers in aquatic food webs from French estuaries. Sci Tot Environ 2006; 368, 615-626.

BSEF, 2011. Bromine Science and Environmental Forum, www.bsef.com.

Christensen JH, Glasius M, Pécseli M, Platz J, Pritzl G. Polybrominated diphenyl ethers (PBDEs) in marine fish and blue mussels from southern Greenland. Chemosphere 2002; 47, 631-638.

Courrat A, Lobry J, Nicolas D, Laffargue P, Amara R, Lepage M, Girardin M, Le Pape $O$. Anthropogenic disturbance on nursery function of estuarine areas for marine species. Estuar Coast Shelf Sci 2009; 81, 179-190.

Covaci A, Harrad S, Abdallah MAE, Ali N, Law RJ, Herzke D, de Wit CA. Novel brominated flame retardants: A review of their analysis, environmental fate and behaviour. Environ Int 2011; 37, 532-556.

de Boer J, Wester PG, van der Host A, Leonards PEG. Polybrominated diphenyl ethers in influents, suspended particulate matter, sediments, sewage treatment plant and effluents and biota from the Netherlands. Environ Pollut 2003; 122, 63-74.

Decision 2455/2001/EC of 20 November 2001 establishing a list of priority substances in the field of water policy. Official Journal of the European Communities L 331, 15.12.2001, 1.

de Wit CA. An overview of brominated flame retardants in the environment. Chemosphere 2002; 46, 583-624.

de Wit CA, Herzke D, Vorkamp K. Brominated flame retardants in the Arctic environment - trends and new candidates. Sci Tot Environ 2010; 408, 2885-2918.

Directive 2003/11/EC of the European Parliament and of the Council of 6 February 2003. Official Journal of the European Union, 2003, L42/45e46.

Dodder NG, Strandberg B, Hites RA. Concentrations and spatial variations of polybrominated diphenyl ethers and several organochlorine compounds in fishes from the northeastern United States. Environ Sci Technol 2002; 36, 146-151.

Eljarrat E, De La Cal A, Raldua D, Duran C, Barcelo D. Occurrence and bioavailability of polybrominated diphenyl ethers and hexabromocyclododecane in sediment and fish from the Cinca River, a tributary of the Ebro River (Spain). Environ Sci Technol 2004; 38, 2603-2608.

Gaul S, Von der Recke R, Tomy G, Vetter W. Anaerobic transformation of a technical brominated diphenyl ether mixture by super-reduced vitamin B-12 and dicyanocobinamide. Environ Toxicol Chem 2006; 25, 1283-1290.

Gauthier LT, Potter D, Hebert CE, Letcher RJ. Temporal trends and spatial distribution of non-polybrominated diphenyl ether flame retardants in the eggs of colonial populations of Great Lakes herring gulls. Environ Sci Technol 2009; 43, 312-317.

Gieron J, Grochowalski A, Chrzaszcz R. PBB levels in fish from the Baltic and North seas and in selected food products from Poland. Chemosphere 2010; 78, 12721278.

Gilliers C, Amara R, Bergeron JP, Le Pape O. Comparison of growth and condition indices of juvenile flatfish in different coastal nursery grounds. Environ Biol Fish 2004; 71, 189-198.

Gomara B, Herrero L, Gonzalez MJ. Survey of polybrominated diphenyl ether levels in Spanish commercial foodstuffs. Environ Sci Technol 2006; 40, 7541-7547.

Gouteux B, Alaee M, Mabury SA, Pacepavicius G, Muir DCG. Polymeric brominated flame retardants: are they a relevant source of emerging brominated aromatic compounds in the environment ? Environ Sci Technol 2008; 42, 9039-9044. 
Grant SM, Brown JA. Variation in condition of coastal Newfoundland 0-group atlantic cod (Gadus morhua): field and laboratory studies using simple condition indices. Mar Biol 1999; 133, 611-620.

Hardy ML. A comparison of the properties of the major commercial PBDPO/PBDE product to those of major PBB and PCB products. Chemosphere 2002; 46, 717728.

He JZ, Robrock KR, Alvarez-Cohen L. Microbial reductive debromination of polybrominated diphenyl ethers (PBDEs). Environ Sci Technol 2006; 40, 4429-4434.

Hites RA. Polybrominated diphenyl ethers in the environment and in people: a metaanalysis of concentrations. Environ Sci Technol 2004; 38, 945-956.

Hoh E, Zhu L, Hites RA. Novel flame retardants, 1,2-bis(2,4,5,6-tribromophenoxy)ethane and 2,3,4,5,6-pentabromoethylbenzene, in United States environmental samples. Environ Sci Technol 2005; 39, 2472-2477.

Ikonomou MG, Rayne S, Fischer M, Fernandez MP, Cretney W. Occurrence and congener profiles of polybrominated diphenyl ethers (PBDEs) in environmental samples from coastal British Columbia, Canada. Chemosphere 2002; 46, 649-663.

Ikonomou MG, Fernandez MP, Hickman ZL. Spatio-temporal and species-specific variation in PBDE levels/patterns in British Columbia's coastal waters. Environ Pollut 2006; 140, 355-363.

Ismail N, Gewurtz SB, Pleskach K, Whittle DM, Helm PA, Marvin CH, Tomy GT. Brominated and chlorinated flame retardants in Lake Ontario, Canada, lake trout (Salvelinus Namaycush) between 1979 and 2004 and possible influences of foodweb changes. Environ Toxicol Chem 2009; 28, 910-920.

Jenssen BM, Sormo EG, Baek K, Bytingsvik J, Gaustad H, Ruus A, Skaare JU. Brominated flame retardants in North-East Atlantic marine ecosystems. Environ Health Perspect 2007; 115, 35-41.

Johansson I, Moisan K, Guiot N, Truquet I, Munschy C, Tronczyński J. Polybrominated diphenyl ethers (PBDEs) in mussels from selected French coastal sites: 1981-2003. Chemosphere 2006; 64, 296-305.

Kierkegaard A, Balk L, Tjärnlund U, De Wit C, Jansson B. Dietary uptake and biological effects of decabromodiphenyl ether in rainbow trout (Oncorhynchus mykiss). Environ Sci Technol 1999; 33, 1612-1617.

Kierkegaard $A$, Björklund $\mathrm{J}$, Friden $\mathrm{U}$. Identification of the flame retardant decabromodiphenyl ethane in the environment. Environ Sci Technol 2004; 38, 32473253.

Labandeira A, Eljarrat E, Barcelo D. Congener distribution of polybrominated diphenyl ethers in feral carp (Cyprinus carpio) from the Llobregat river, Spain. Environ Pollut 2007; 146, 188-195.

La Guardia MJ, Hale RC, Harvey E. Detailed polybrominated diphenyl ether (PBDE) congener composition of the widely-used penta-, octa-, and deca-PBDE technical flame-retardant mixtures. Environ Sci Technol 2006; 40, 6247-6254.

Lair GJ, Zehetner F, Fiebig M, Gerzabek MH, van Gestel CAM, Hein T, Hohensinner S, Hsu P, Jones KC, Jordan G, Koelmans AA, Poot A, Slijkerman DME, Totsche KU, Bondar-Kunze E, Barth JAC. How do long-term development and periodical changes of river-floodplain systems affect the fate of contaminants ? Results from European rivers. Environ Pollut 2009; 157, 3336-3346.

Law RJ, Alaee M, Allchin CR, Boon JP, Lebeuf M, Lepom P, Stern GA. Levels and trends of polybrominated diphenylethers and other brominated flame retardants in wildlife. Environ Int 2003; 29, 757-770.

Law K, Halldorson T, Danell R, Stern G, Gewurtz S, Alaee M, Marvin C, Whittle M, Tomy G. Bioaccumulation and trophic transfer of some brominated flame retardants in a Lake Winnipeg (Canada) food web. Environ Toxicol Chem 2006a; 25, 21772186. 
Law RLJ, Allchin CR, de Boer J, Covaci A, Herzke D, Lepom P, Morris S, Tronczynski $\mathrm{J}$, de Wit $\mathrm{C}$. Levels and trends of brominated flame retardants in the European environment. Chemosphere 2006b; 64, 187-208.

Law RJ, Herzke D, Harrad S, Morris S, Bersuder P, Allchin CR. Levels and trends of HBCD and BDEs in the European and Asian environments, with some information for other BFRs. Chemosphere 2008; 73, 223-241.

Legler J. New insights into the endocrine disrupting effects of brominated flame retardants. Chemosphere 2008; 73, 216-222.

Lepom P, Haarich M, Sawal G, Warmbrunn-Suckrow E. Polybrominated diphenyl ethers in dab (Limanda limanda L.) from the North and Baltic Sea. Organohalogen Compounds 2006; 68, 1792-1795.

Li QZ, Yan CZ, Luo ZX, Zhang X. Occurrence and levels of polybrominated diphenyl ethers (PBDEs) in recent sediments and marine organisms from Xiamen offshore areas, China. Mar Pollut Bull 2010; 60, 464-469.

Meng XZ, Yu L, Guo Y, Mai BX, Zeng EY. Congener-specific distribution of polybrominated diphenyl ethers in fish of China: implication for input sources. Environ Toxicol Chem 2008; 27, 67-72.

Möller A, Xie Z, Surm R, Ebinghaus R. Polybrominated diphenyl ethers (PBDEs) and alternative brominated flame retardants in air and seawater of the European Arctic. Environ Pollut 2011; 159, 1577-1583.

Munschy C, Héas-Moisan K, Loizeau V, Tixier C, Tronczynski J, Alaee $M$, Pacepavicius G. Identification of past and novel brominated flame retardants in common sole (Solea solea L.) from coastal areas in France. Organohalogen Compounds 2007; 69, 2681-2685.

Munschy C, Guiot N, Heas-Moisan K, Tixier C, Tronczynski J. Polychlorinated dibenzop-dioxins and dibenzofurans (PCDD/Fs) in marine mussels from French coasts: levels, patterns and temporal trends from 1981 to 2005. Chemosphere 2008; 73, 945-953.

Munschy C, Héas-Moisan K, Tixier C, Olivier N, Gastineau O, Le Bayon N, Buchet V. Dietary exposure of juvenile common sole (Solea solea L.) to polybrominated diphenyl ethers (PBDEs): Part 1. Bioaccumulation and elimination kinetics of individual congeners and their debrominated metabolites. Environ Pollut 2011; 159, 229-237.

Nicolas D, Le Loc'h F, Désaunay Y, Hamon D, Blanchet A, Le Pape O. Relationships between benthic macrofauna and habitat suitability for juvenile common sole (Solea solea, L.) in the Vilaine estuary (Bay of Biscay, France) nursery ground. Est Coast Shelf Sci 2007; 73, 639-650.

Paepke O, Herrmann T. Polybrominated diphenylethers (PBDEs) in fish samples of various origin. Organohalogen Compounds 2004; 66, 3921-3926.

Peng JH, Huang CW, Weng YM, Yak HK. Determination of polybrominated diphenyl ethers (PBDEs) in fish samples from rivers and estuaries in Taiwan. Chemosphere 2007; 66, 1990-1997.

Qiu XH, Zhu T, Hu JX. Polybrominated diphenyl ethers (PBDEs) and other flame retardants in the atmosphere and water from Taihu Lake, East China. Chemosphere 2010; 80, 1207-1212.

Rayne S, Ikonomou MG, Antcliffe B. Rapidly increasing polybrominated diphenyl ether concentrations in the Columbia River system from 1992 to 2000. Environ Sci Technol 2003; 37, 2847-2854.

Rice CP, Chernyak SM, Begnoche L, Quintal R, Hickey J., 2002. Comparisons of PBDE composition and concentration in fish collected from the Detroit river, $\mathrm{MI}$ and Des Plaines River, IL. Chemosphere 2002; 49, 731-737. 
Ricklund N, Kierkegaard A, McLachlan MS. An international survey of decabromodiphenyl ethane (DBDPE) and decabromodiphenyl ether (DecaBDE) in sewage sludge samples. Chemosphere 2008; 73, 1799-1804.

Ricklund N, Kierkegaard A, McLachlan MS. Levels and potential sources of decabromodiphenyl ethane (DBDPE) and decabromodiphenyl ether (DecaBDE) in lake and marine sediments in Sweden. Environ Sci Technol 2010; 44, 1987-1991.

Riou P, Le Pape O, Rogers SI. Relative contributions of different sole and plaice nurseries to the adult population in the Eastern Channel: application of a combined method using generalized linear models and a geographic information system. Aquat Living Resour 2001; 14, 125-135.

Rochette S, Rivot E, Morin J, Mackinson S, Riou P, Le Pape O. Effect of nursery habitat degradation on flatfish population: application to Solea solea in the Eastern Channel (Western Europe). J Sea Res 2010; 64, 34-44.

Roosens L, Geeraerts C, Belpaire C, Van Pelt I, Neels H, Covaci A. Spatial variations in the levels and isomeric patterns of PBDEs and HBCDs in the European eel in Flanders. Environ Int 2010; 36, 415-423.

Roots O, Zitko V, Kiviranta H, Rantakokko P, Ruokojärvi P. Polybrominated diphenyl ethers in Baltic herring from Estonian waters, 2006-2008. Russ J Gen Chem 2010; 80, 2721-2730.

Ross PS, Couillard CM, Ikonomou MG, Johannessen SC, Lebeuf M, Macdonald RW, Tomy GT. Large and growing environmental reservoirs of Deca-BDE present an emerging health risk for fish and marine mammals. Mar Pollut Bull 2009 ; 58, 7-10.

Shaw SD, Kannan K. Polybrominated diphenyl ethers in marine ecosystems of the American continents: foresight from current knowledge. Rev Environ Health 2009; 24, 157-229.

Shi T, Chen SJ, Luo XJ, Zhang XL, Tang CM, Luo Y, Ma YJ, Wu JP, Peng XZ, Mai BX. Occurrence of brominated flame retardants other than polybrominated diphenyl ethers in environmental and biota samples from southern China. Chemosphere 2009; 74, 910-916.

Sjödin A, Jones RS, Focant JF, Lapeza C, Wang RY, McGahee EE, Zhang YL, Turner WE, Slazyk B, Needham LL, Patterson DG. Retrospective time-trend study of polybrominated diphenyl ether and polybrominated and polychlorinated biphenyl levels in human serum from the United States. Environ Health Perspect 2004; 112, 654-658.

Söderström G, Sellström U, de Wit CA, Tysklind M. Photolytic Debromination of Decabromodiphenyl Ether (BDE 209). Environ Sci Technol 2004; 38, 127-132.

Sormo E G, Jenssen BM, Lie E, Skaare JU. Brominated flame retardants in aquatic organisms from the North Sea in comparison with biota from the high Arctic marine environment. Environ Toxicol Chem 2009; 28, 2082-2090.

Stapleton HM, Alaee M, Letcher RJ, Baker JE. Debromination of the flame retardant decabromodiphenyl ether by juvenile carp (Cyprinus carpio) following dietary exposure. Environ Sci Technol 2004a; 38, 112-119.

Stapleton HM, Letcher RJ, Baker JE. Debromination of polybrominated diphenyl ether congeners BDE 99 and BDE 183 in the intestinal tract of the common carp (Cyprinus carpio). Environ Sci Technol 2004b; 38, 1054-1061.

Stapleton HM, Brazil B, Holbrook RD, Mitchelmore CL, Benedict R, Konstantinov A, Potter D. In vivo and in vitro debromination of decabromodiphenyl ether (BDE 209) by juvenile rainbow trout and common carp. Environ Sci Technol 2006; 40, 46534658.

Stapleton HM, Allen JG, Kelly SM, Konstantinov A, Klosterhaus S, Watkins D, McClean MD, Webster TF. Alternate and New Brominated Flame Retardants Detected in U.S. House Dust. Environ Sci Technol 2008; 42, 6910-6916. 
Stockholm Convention, 2009. The 9 New POPs under the Stockholm Convention. http://chm.pops.int/Programmes/New\%20POPs/The\%209\%20new\%20POPs/tabid/6 72/language/en-US/Default.aspx.

Tanabe S. Temporal trends of brominated flame retardants in coastal waters of Japan and South China: Retrospective monitoring study using archived samples from esBank, Ehime University, Japan. Mar Pollut Bull 2008; 57, 267-274.

Thoma $\mathrm{H}$, Hutzinger 0 . Pyrolysis and GC/MS analysis of brominated flame retardants in on-line operation. Chemosphere 1987; 16, 1353-1360.

Tian SY, Zhu LY, Liu M. Bioaccumulation and distribution of polybrominated diphenyl ethers in marine species from Bohai Bay, China. Environ Toxicol Chem 2010; 29, 2278-2285.

Tomy GT, Palace VP, Halldorson T, Braekevelt E, Danell R, Wautier K, Evans B, Brinkworth L, Fisk AT. Bioaccumulation, biotransformation and biochemical effects of brominated diphenyl ethers in juvenile lake trout (Salvelinus namaycush). Environ Sci Technol 2004; 38, 1496-1504.

Tomy GT, Palace VP, Pleskach K, Ismail N, Oswald T, Danell R, Wautier K, Evans B. Dietary exposure of juvenile rainbow trout (Oncorhynchus mykiss) to 1,2-bis(2,4,6tribromophenoxy)ethane: bioaccumulation parameters, biochemical effects, and metabolism. Environ Sci Technol 2007; 41, 4913-4918.

Verreault J, Gebbink WA, Gauthier LT, Gabrielsen GW, Letcher RJ. Brominated flame retardants in glaucous gulls from the Norwegian Arctic: More than just an issue of polybrominated diphenyl ethers. Environ Sci Technol 2007; 41, 4925-4931.

Vives I, Grimalt JO, Lacorte S, Guillamon M, Barcelo D, Rosseland BO. Polybromodiphenyl ether flame retardants in fish from lakes in European high mountains and Greenland. Environ Sci Technol 2004; 38, 2338-2344.

von der Recke R, Vetter W. Congener pattern of hexabromobiphenyls in marine biota from different proveniences. Sci Total Environ 2008; 393, 358-366.

Voorspoels S, Covaci A, Schepens P. Polybrominated diphenyl ethers in marine species from the Belgian North Sea and the Western Scheldt estuary: levels, profiles, and distribution. Environ Sci Technol 2003; 37, 4348-4357.

Watanabe I, Kashimoto T, Tatsukawa R. Hexabromobenzene and its debrominated compounds in river and estuary sediments in Japan. Bull. Environ Contam Toxicol 1986; 36, 778-784.

Watanabe I, Sakai S. Environmental release and behavior of brominated flame retardants. Environ Int 2003; 29, 665-682.

Wu JP, Guan YT, Zhang Y, Luo XJ, Zhi H, Chen SJ, Mai BX. Trophodynamics of hexabromocyclododecanes and several other non-PBDE brominated flame retardants in a freshwater food web. Environ Sci Technol 2010; 44, 5490-5495.

Wu JP, Guan YT, Zhang Y, Luo XJ, Zhi H, Chen SJ, Mai BX. Several current-use, nonPBDE brominated flame retardants are highly bioaccumulative: evidence from field determined bioaccumulation factors. Environ Int 2011; 37, 210-215.

Yamaguchi Y, Kawano M, Tatsukawa R, Moriwaki S. Hexabromobenzene and its debrominated compounds in human adipose tissues of Japan. Chemosphere 1988; 17, 703-707.

Zeng X, Massey Simonich SL, Robrock KR, Korytar P, Alvarez-Cohen L, Barofsky DF. Application of a congener-specific debromination model to study photodebromination, anaerobic microbial debromination, and $\mathrm{Fe} 0$ reduction of polybrominated diphenyl ethers. Environ Toxicol Chem 2010; 27, 67-72.

Zhao X, Zhang H, Fan J, Guan D, Zhao H, Ni Y, Chen J. Dioxin-like compounds in sediments from the Daliao river estuary of Bohai Sea: distribution and their influencing factors. Mar Pollut Bull 2011; 62, 918-925. 
Figure 1 : Sampling locations for juvenile sole in main nursery zones along French coasts

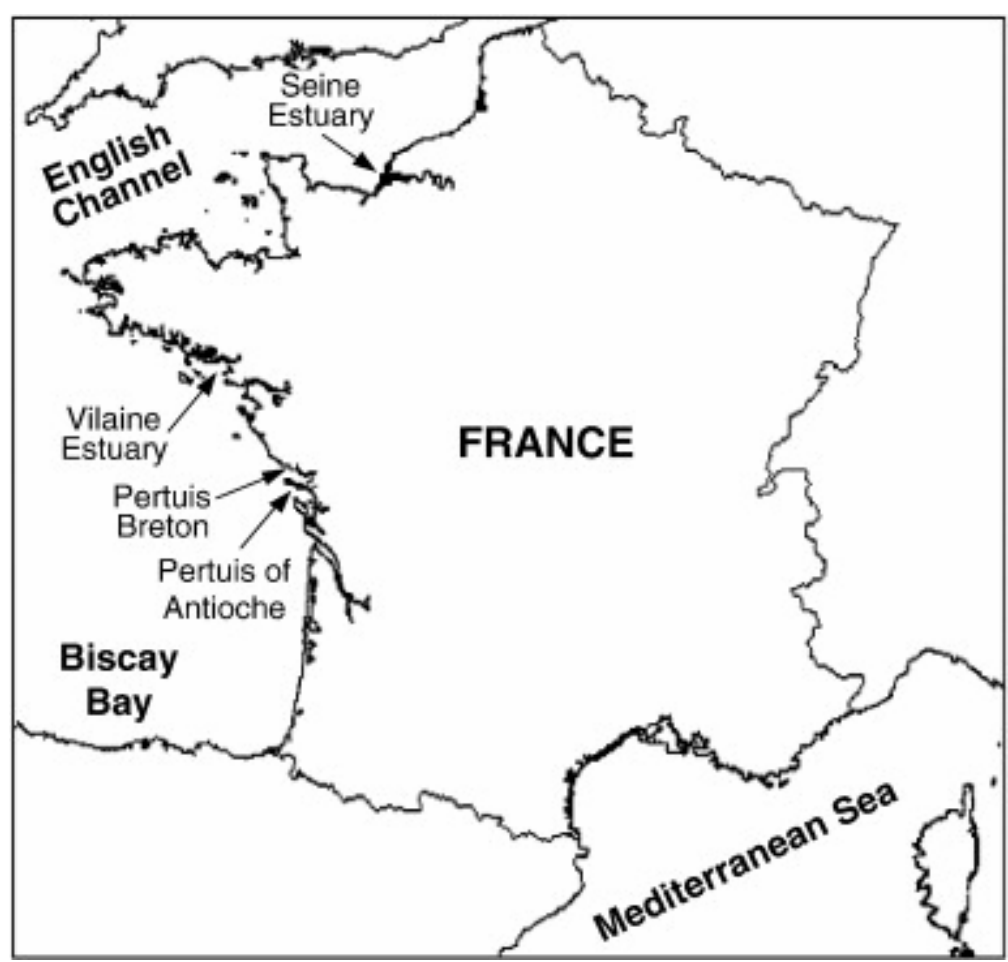


Figure 2 : PBDE concentrations ( $\mathrm{ng} \mathrm{g}^{-1} \mathrm{ww}$ and $\mathrm{ng} \mathrm{g}^{-1} \mathrm{Iw}$, sum of 14 congeners) in muscle and liver samples of sole collected from main nursery zones along French coasts. Mean values and standard deviations are indicated. ZA, ZB, ZC are for the different sampling zones in the Seine estuary, $\mathrm{Vi}=$ Vilaine estuary, $\mathrm{PA}=$ Pertuis of Antioche, PB=Pertuis Breton. -07, -08, -09 are for 2007, 2008 and 2009, respectively. nda: no data available
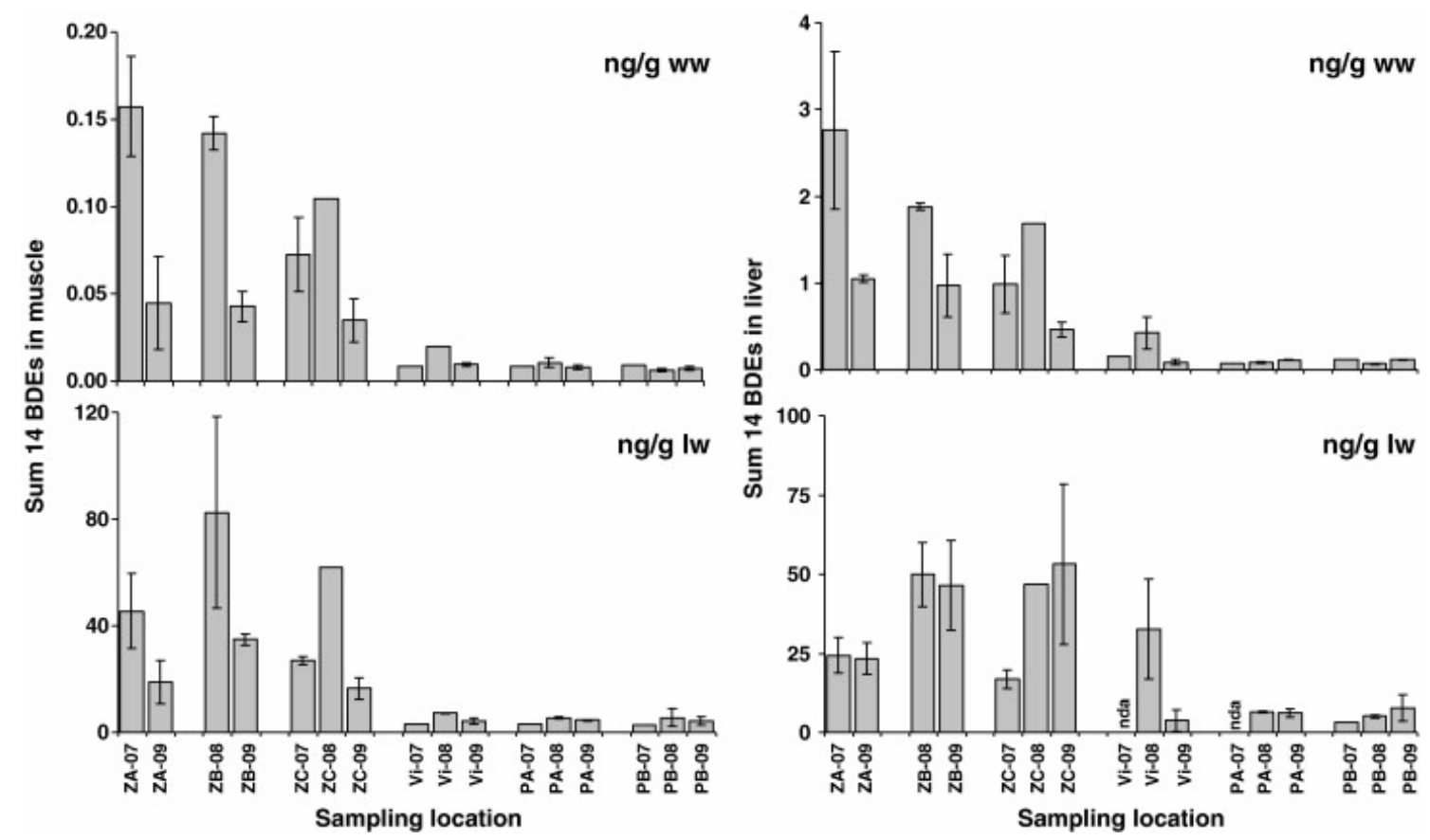

Figure 3 : PBDE congener patterns in muscle samples of sole collected in 2007, 2008 and 2009 from main nursery zones along French coasts. Mean values and standard deviations are presented

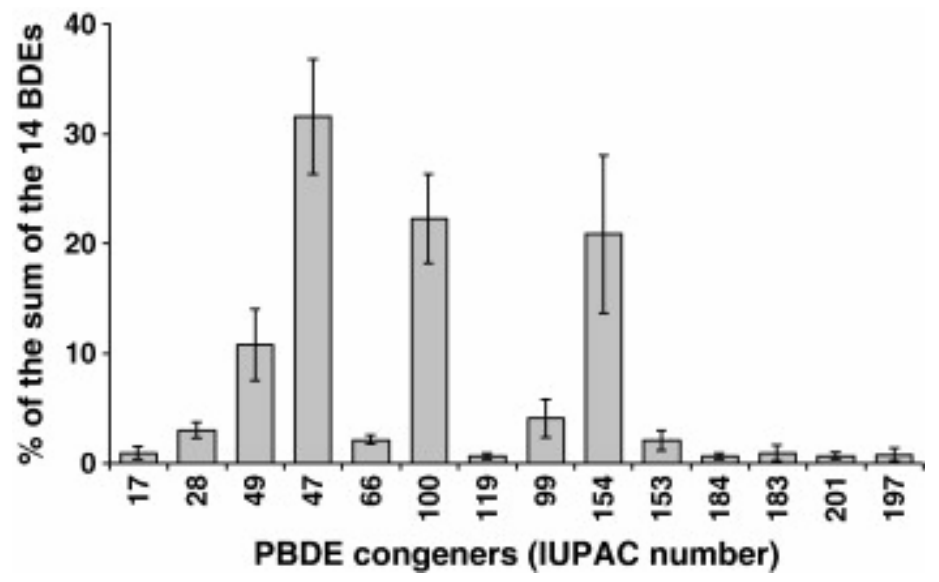


Figure 4: Comparison of PBDE congener patterns in sole muscle samples (mean pattern, $n=35$ ) and in the three PBDE commercial mixtures 70-5 DE, 79-8 DE and 300 BA. Patterns are presented according to the number of bromine atoms

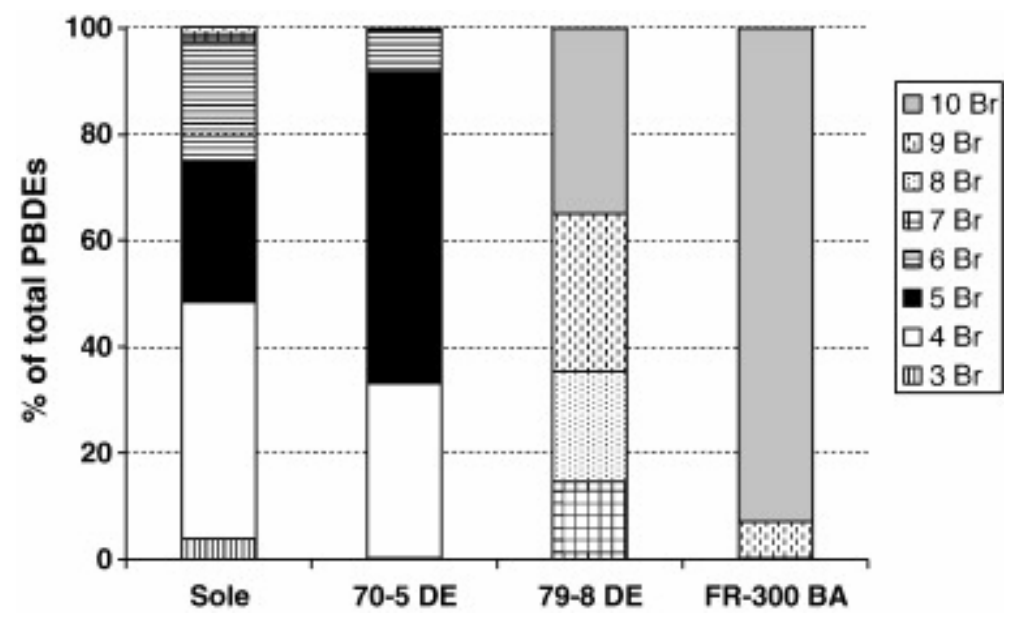


Table 1 : BDE-47 concentration ranges in bottom feeder fish from various estuarine or coastal areas in Europe (including this study). Results are expressed in ng/g ww

\begin{tabular}{lcccc}
\hline \multirow{2}{*}{ Location } & Organism & \multicolumn{2}{c}{ BDE-47 } & Reference \\
& & Muscle & Liver & \\
\hline France (English Channel) & Common sole & $\mathbf{0 . 0 1 - 0 . 0 5}$ & $\mathbf{0 . 1 4 - 0 . 8 7}$ & This study \\
France (Atlantic coast) & Common sole & $\mathbf{0 . 0 0 2 - 0 . 0 1}$ & $\mathbf{0 . 0 2 - 0 . 2 4}$ & This study \\
& & & & \\
France (Loire estuary) & Common sole & $0.09-0.39$ & nda & Bragigand et al., 2006 \\
France (Loire estuary) & Flounder & $0.06-0.5$ & nda & Bragigand et al., 2006 \\
France (Seine estuary) & Flounder & $0.42-4.15$ & nda & Bragigand et al., 2006 \\
& & & & \\
The Netherlands (North Sea) & Common sole & $0.04-0.34$ & $0.39-3.7$ & Voorspoels et al., 2003 \\
& Other benthic fish & $0.04-0.31$ & $1.9-8.3$ & Voorspoels et al., 2003 \\
& Common sole & $0.05-3.9$ & $8.3-47.7$ & Voorspoels et al., 2003 \\
The Netherlands & Other benthic fish & $0.05-7.1$ & $12.2-186$ & Voorspoels et al., 2003 \\
North Sea - Baltic Sea & Flounder & $0.07-3.24$ & nda & De Boer et al., 2003 \\
Southern Greenland & Dab & & $1.78-7.18$ & Lepom et al., 2006 \\
Norway & Benthic fish & $1.10-7.81$ & nda & Christensen et al., 2002 \\
& Halibut & $0.15-14.54$ & nda & Bethune et al., 2004 \\
& Flatfish & $0.11-0.18$ & nda & Berge et al., 2006 \\
North and North-East Atlantic & Benthic fish & $0.12-0.81$ & nda & Sormo et al., 2009 \\
& Benthic fish & $0.05-0.67^{\mathrm{a}}$ & & Paepke and Herrmann, 2004 \\
\hline
\end{tabular}

${ }^{\mathrm{a}}$ Concentrations were recalculated in ng/g ww with the lipid content given in the publication, assuming that this lipid content was in \% ww.

nda: no data available 
Table 2 : Concentration ranges (min-max (mean) in $\mathrm{pg} / \mathrm{g} \mathrm{ww}$ ) of non-PBDE BFRs in the muscle and liver of juvenile sole collected from the English Channel (Seine Bay) and Atlantic coast (Vilaine Bay, Pertuis of Antioche and Pertuis Breton) during the 3-year study. LOD stands for Limit of Detection (see section 2.5)

\begin{tabular}{|c|c|c|c|c|c|c|}
\hline \multirow[t]{2}{*}{ MUSCLE } & \multicolumn{3}{|c|}{ Seine Bay } & \multirow[t]{2}{*}{$\begin{array}{c}\text { Vilaine } \\
\text { Bay }\end{array}$} & \multirow[t]{2}{*}{$\begin{array}{c}\text { Pertuis of } \\
\text { Antioche }\end{array}$} & \multirow[t]{2}{*}{$\begin{array}{l}\text { Pertuis } \\
\text { Breton }\end{array}$} \\
\hline & $Z A$ & $Z B$ & $Z C$ & & & \\
\hline \multicolumn{7}{|l|}{$(\mathrm{pg} / \mathrm{g} \mathrm{ww})$} \\
\hline ВТВРЕ & $0.04-1.2(0.7)$ & $0.05-0.9(0.4)$ & $<$ LOD-0.4 (0.2) & $0.1-0.6(0.3)$ & < LOD-1.0 (0.6) & < LOD-1.4 (0.6) \\
\hline DBDPE & $<$ LOD-1.0 (0.9) & $1.0-3.5(1.9)$ & < LOD-1.5 (1.0) & < LOD-3.3 (1.9) & < LOD-1.3 (1.0) & < LOD-1.6 (1.0) \\
\hline HBB & $<$ LOD-2.0 (1.7) & $0.3-1.2(0.9)$ & $<$ LOD-1.1 (0.9) & $0.7-5.1(2.6)$ & $1.7-4.3(2.8)$ & $1.2-2.9(2.0)$ \\
\hline BB-153 & $1.0-4.5(3.0)$ & $1.5-3.8(2.5)$ & $1.0-3.1(2.0)$ & $0.1-0.2(0.1)$ & $0.1-0.2(0.1)$ & $0.1(0.1)$ \\
\hline \multirow[t]{2}{*}{ LIVER } & \multicolumn{3}{|c|}{ Seine Bay } & \multirow[t]{2}{*}{$\begin{array}{c}\text { Vilaine } \\
\text { Bay }\end{array}$} & \multirow[t]{2}{*}{$\begin{array}{c}\text { Pertuis of } \\
\text { Antioche }\end{array}$} & \multirow[t]{2}{*}{$\begin{array}{l}\text { Pertuis } \\
\text { Breton }\end{array}$} \\
\hline & $Z A$ & $Z B$ & $\mathrm{ZC}$ & & & \\
\hline \multicolumn{7}{|l|}{ (pg/g ww) } \\
\hline BTBPE & $0.5-72.4(30.5)$ & < LOD-10.1 (7.0) & < LOD-12.5 (7.1) & $<$ LOD-11.2 (5.3) & $<$ LOD-68.8 (40.2) & $<$ LOD-48.3 (26.7) \\
\hline DBDPE & 8.4-21.1 (14.2) & $<$ LOD & $11.2-20.6(13.8)$ & < LOD-17.4 (12.2) & $<$ LOD-18.2 (11.5) & $<$ LOD-19.6 (13.7) \\
\hline HBB & $<$ LOD-4.7 (3.9) & 5.0-41.1 (15.6) & $<$ LOD-31.1 (10.1) & $13-199.4(54.3)$ & $4.2-22.2(13.0)$ & $6.5-34.0(24.1)$ \\
\hline BB-153 & 26.6-97.0 (56.2) & 23.0-49.7 (41.7) & $17.9-60.6(30.8)$ & $<$ LOD-1.4 (1.0) & $0.7-1.33(1.0)$ & $0.6-1.9(1.0)$ \\
\hline
\end{tabular}

